\title{
CAPABILITY BUILDING IN FUZZY FRONT END MANAGEMENT IN A HIGH TECHNOLOGY SERVICES COMPANY
}

\author{
CONSTRUÇÃO DE CAPACITAÇÃO PARA A LINHA DE FRENTE (FUZZY FRONT END) DA \\ INOVAÇÃO EM UMA EMPRESA DE ALTA TECNOLOGIA
}

\author{
CREACIÓN DE FORMACIÓN PARA EL FUZZY FRONT END OF INNOVATION EN UNA \\ EMPRESA DE ALTA TECNOLOGÍA
}

\author{
Claudio Marcos Vigna ${ }^{1}$ \\ Abraham Sin Oih $\mathbf{Y u}^{2}$ \\ Paulo Tromboni Nascimento ${ }^{3}$ \\ Edison Fernandes Polo ${ }^{4}$ \\ Ana Maria Gati ${ }^{5}$
}

\section{Cite as - American Psychological Association (APA)}

Vigna, C. M., Yu, A. S. O., Nascimento, P. T., Polo, E. F., \& Gati, A. M. (2020, May/Aug.). Capability building in fuzzy front end management in a high technology services company. International Journal of Innovation - IJI, São Paulo, 8(2), 223-249. https://doi.org/10.5585/iji.v8i2.18045.
Abstract
The purpose of this paper is to evaluate the adherence between the Fuzzy Front End (FFE)' enablers, reported in the literature, and its application in the innovation process of a very innovative multinational company of high-tech services.
To investigate how a company should manage its resources and processes to efficiently manage the FFE phase of PPD, this work included conducting field research based on the case study method.
To succeed with this goal, this paper is structured as follows: at first moment we present a theoretical background to capture the key enablers for efficient management of the FFE. Subsequently, based on these findings, a questionnaire was structured and applied during the case development, resulting in assessing the applicability of these theoretical elements in the company
This paper is justified in this context, evidenced by the importance of capability building in FFE management. The FFE isn't fully understood by the managers and it is considered as a major weakness in the innovation process .

\footnotetext{
${ }^{1}$ Universidade de São Paulo - FEA-USP, São Paulo, São Paulo - Brasil. claudiovigna@ hotmail.com

${ }^{2}$ Universidade de São Paulo - FEA-USP, São Paulo, São Paulo - Brasil. abraham_sinoih_yu@ @otmail.com

${ }^{3}$ Universidade de São Paulo - FEA-USP, São Paulo, São Paulo - Brasil. tromboni@ usp.br

${ }^{4}$ Universidade de São Paulo - FEA-USP, São Paulo, São Paulo - Brasil. polo@ usp.br

${ }^{5}$ Universidade de São Paulo - FEA-USP, São Paulo, São Paulo - Brasil. anagati64@ gmail.com
} 
As a theorical contribution we identify, in the literature review, 14 FFE enablers. Other important contribution is the framework elaborated to assess the process's maturity of the FFE Management in the case. As a social contribution we identified if the enablers were applicable in the FFE Management in the company.

Keywords: Front fuzzy end. Capability building. High technology services company.

\section{Resumo}

O objetivo deste artigo é avaliar a aderência entre os facilitadores do Fuzzy Front End (FFE), relatados na literatura, e sua aplicação no processo de inovação de uma inovadora empresa multinacional de serviços de alta tecnologia.

Para investigar como uma empresa deve gerenciar seus recursos e processos para obter eficiência a fase FFE, este trabalho incluiu a realização de uma pesquisa de campo com base no método de estudo de caso.

Para alcançar este objetivo, o artigo está estruturado da seguinte forma: num primeiro momento apresentamos um embasamento teórico para captar os principais capacitadores para uma gestão eficiente da FFE. Posteriormente, com base nessas constatações, foi estruturado e aplicado um questionário durante o desenvolvimento do estudo de caso, resultando na avaliação da aplicabilidade desses elementos teóricos na empresa.

Este artigo se justifica neste contexto, evidenciado pela importância da capacitação na gestão de FFE. O FFE não é totalmente compreendido pelos gestores e é considerado um dos principais pontos fracos do processo de inovação.

Como contribuição teórica identificamos, na revisão da literatura, 14 facilitadores de FFE. Outra contribuição importante é o framework elaborado para avaliar a maturidade do processo de Gestão do FFE no caso. Como contribuição social nós identificamos se os habilitadores eram aplicáveis na gestão do FFE na empresa.

Palavras-chave: Front fuzzy end. Capacitação. Empresa de serviços de alta tecnologia.

\section{Resumen}

El propósito de este artículo es evaluar la adherencia entre los facilitadores de Fuzzy Front End (FFE), reportados en la literatura, y su aplicación en el proceso de innovación de una innovadora empresa multinacional de servicios de alta tecnología.

Para investigar cómo una empresa debe administrar sus recursos y procesos para obtener eficiencia en la fase FFE, este trabajo incluyó la realización de una investigación de campo basada en el método de estudio de caso.

Para lograr este objetivo, el artículo se estructura de la siguiente manera: en un primer momento, presentamos una base teórica para captar los principales formadores para una gestión eficiente de la FFE. Posteriormente, a partir de estos hallazgos, se estructuró y aplicó un cuestionario durante el desarrollo del estudio de caso, dando como resultado la evaluación de la aplicabilidad de estos elementos teóricos en la empresa.

Este artículo se justifica en este contexto, evidenciado por la importancia de la formación en el manejo de la FFE. Los gerentes no comprenden completamente la FFE y se considera una de las principales debilidades del proceso de innovación.

Como aporte teórico, identificamos, en la revisión de la literatura, 14 facilitadores del PEF. Otro aporte importante es el marco diseñado para evaluar la madurez del proceso de Gestión FFE en el caso. Como aporte social, identificamos si los habilitadores eran aplicables a la gestión de FFE en la empresa.

Palabra clave: Front fuzzy end. Capacitación. Empresa de servicios de alta tecnología. 


\section{Introduction}

Managers and executives in different sectors adopt innovative practices to get a competitive edge in their respective markets (Jetter, 2003, Lacom, Bazzaro \& Sagot, 2017). There are several surveys pointing that companies focusing on innovation overcome their competitors in terms of market share, profitability and growth (Tidd, Bessant \& Pavitt, 2005).

A PPD model can be divided into three phases: the theoretical proposal, or Fuzzy Front End (FFE), that is concentrated in the pre-development activities, the technical design, or development phase, which turns the theory into products, and marketing, which seeks to give effect to the benefits that result from the innovation (Trott, 2005). The FFE is cited by several authors as an important activity because it can act in the success of the development of a new product (Khuran \& Rosenthal, 1997, Kim \& Wilemon, 2002, Koen et al., 2001, Verworn, 2009) and can affect the overall performance of the PPD, increasing the time to market in the release of new products (Jetter, 2003).

A company that competes based on innovation strategy should be effective in all phases of the PPD, but especially in the FFE, because in this stage the senior manager makes the decision of "go" or "no go" in terms of a new product development project (Jetter, 2003, Stevens, 2014).

Despite being crucial to the success of innovation and providing opportunities for improvement in the innovation process, the FFE is not fully understood by the managers and is considered to be a major weakness in the innovation process (Khuran \& Rosenthal, 1997, Currano \& Steinert, 2012). Verworn (2009) confirms and suggests that the FFE often receives poor attention from the management team, as well as limited resources. Koen et al. (2001) conducted a quantitative survey with 23 companies that studied the correlation between competence in FEE and high degree of innovation. According to the authors, there is evidence of high correlation between competence in the FFE and development of successful innovation projects.

Hyypiä and Parjanen (2013) and Jetter (2003) explain the FFE as an emerging practice on which several researchers have focused efforts analyzing the application of different models in various business sectors and consequently suggested approaches that are theoretically more efficient in improving management of the FFE process. Jetter (2003) reports that, despite these efforts, it is still possible to see many companies that do not have an efficient management of the FFE. They elaborate this phase based on "intuition" or "guesswork processes" instead of the adoption of structured methods. In Brazil the situation is not different, except in some big 
companies that have a good level of maturity in the FFE management. It is possible that most companies in Brazil have an incipient level of proficiency in FEE management.

This paper is justified in this context, evidenced by the importance of capability building in FFE management. The purpose of this paper is to evaluate if the enablers identified in the literature on FFE management are really applied in the case. To succeed with this goal, this paper is structured as follows: at a first moment, we present a theoretical background to capture the key enablers for efficient management of the FFE. Subsequently, based on these findings, a questionnaire was structured and applied during the case development, resulting in assessing the applicability of these theoretical elements in the company. Finally, with these procedures, it will be possible to answer the research questions:

Theoretical issue:

Q1) What are the organizational resources and operational techniques that enable the company to efficiently manage the FFE?

Practical issue:

Q2) Are organizational resources and operational techniques raised in literature review applied to the company's case?

As a result, the main findings through this case study will be presented, providing the basis for academics to produce future research about the cause and effect in the relationship of the enablers and to practitioners to have an applicable model that is adherent to the reality of their respective market. The expected contribution to the theory is the update of the theoretical practices raised by authors and the elimination of the practices used in the market in FFE management.

\section{Theoretical Background}

\subsection{Innovation, PPD and FFE}

There are, in the literature, different definitions for the term "innovation". Innovation can be represented as the ability to identify and take advantage of opportunities, not limited to discovering new markets, but also to improving the processes to serve the markets already consolidated (Tidd et al., 2005, Berghaus \& Back, 2017). This view confirms the definition of other authors that points to the industrial innovation as the development of a new process or product, which is a combination of entrepreneurship with synchrony between new ideas and market (Clark \& Wheelwright, 1993). We adopt, in this paper, the term "innovation" as a new product, process change or method improvement (OECD, 2005). 
The effort made by a company in processing the data about market opportunities and technical possibilities in products and information for the production of a commercial product is defined as PPD (Krishnan \& Ulrich, 2001). A company that wishes to have a focus on innovation must develop a systematic approach named PPD. Ulrich and Eppinger (1995) defines the PPD as the process that transforms the information of market opportunities and process improvements into subsidies for the development of innovation in product and process with a commercial perspective. For purposes of conceptual alignment, we will adopt the classification developed by Clark and Wheelwright (1993) to characterize the different types of innovation projects:

- Radical projects or radical innovations: usually from the development of new technologies;

- Derivative projects or incremental innovation: innovation performed based on products already developed;

- Platform Projects: the product platforms are developed and, from these, new products are then developed, always integrated into the initial platform.

The trigger of PPD processes can be performed through different modus operandi. In his book, Trott (2005) mentions six modus operandi, the first generation being the Push Technology (PT), and the second, the Market Pull (MP). The choice of the modus operandi will influence the capability building and the methods adopted in the companies in order to achieve their goal through innovation. But it is known that the other modus operandi presented are atypical because, in most of the cases, all of them result from an interaction between the TP and MP (Trott, 2005).

Many authors divide the PPD into different stages, but there is no consensus on how many of the stages have a high performance PPD management model. Among the different authors who have different perspectives, some authors accept the proposal that divides the PPD into three phases: theoretical proposal (FFE), the technical design (development of the product itself) and marketing (Trott, 2005). The first phase of theoretical proposal refers to the FFE which is defined as the pre-stage of development consisting in the generation of ideas, conceptual product definition and evaluation of the economic viability (Reinertsen \& Smith, 1991, Trott, 2005). 


\subsection{Fuzzy Front End}

Reinertsen and Smith (1991) coined the term "FFE" in their study in which they highlight the strategic importance of the generation phase of management and the selection of ideas in the PPD. For the authors, the sizing of time and resources in the PPD implementation comes from the results obtained in the FFE. Since then, the activities and early stages of PPD have gained more relevance and have become looked into by practitioners and researchers. The FFE was segmented as the initial part of PPD, enabling the development of several studies that proved a critical success factor for a good performance of PPD (Khuran \& Rosenthal, 1997, Kim \& Wilemon, 2002, Koen et al., 2001, Thanasopon, Papadopoulos \& Vidgen, 2013, Chamakiotisa, Boukisa, Pantelib \& Papadopoulosc, 2020).

The FFE can be considered as a crossroad of complex information to be obtained and processed, as well as a tacit knowledge that brings along organizational pressures and conflicts and, therefore, a considerable degree of uncertainty (Hyypiä \& Parjanen, 2013). There are three types of uncertainty present in the FFE: technological, market and managerial (Stevens, 2014, Rodrigues, Braghini Junior \& Sola 2017). Technological uncertainty is generally defined as the use of new technology versus a mature technology. Market uncertainty is conceptualized in terms of market change or change in market competition (Alblas \& Jayaram, 2014). The uncertainty management consists of a number of factors, such as resource requirements, capacity and business setting, and operational limits (Kim \& Wilemon, 2002).

Several papers have shown as a result of empirical analysis that the reduction of technical and market uncertainties, as well as a better initial planning of the development of new project, have a positive impact on innovation and increase the probability of commercial success of the projects (Jetter, 2003, Thanasopon et al., 2013, Verworn, 2009). These uncertainties are reduced in all dimensions when sufficient information is obtained from various sources to support a reliable analysis of "go - no go" decision (Stevens, 2014). This takes place because quality, cost and time are set mainly in the FFE phase (Verworn \& Herstatt, 2001). For this reason, changes made at this stage affect less an innovation project economically compared to those made at a later time (Stevens, 2014, Thanasopon et al., 2013).

\subsubsection{FFE management framework}

Since researchers began to focus on efforts to elucidate and enhance knowledge in FFE management, many models have been proposed. Among them, we adopted the model of (Koen 
et al., 2001), illustrated in Figure 1, which contributes to a holistic view of the FFE in simplified form and practice.

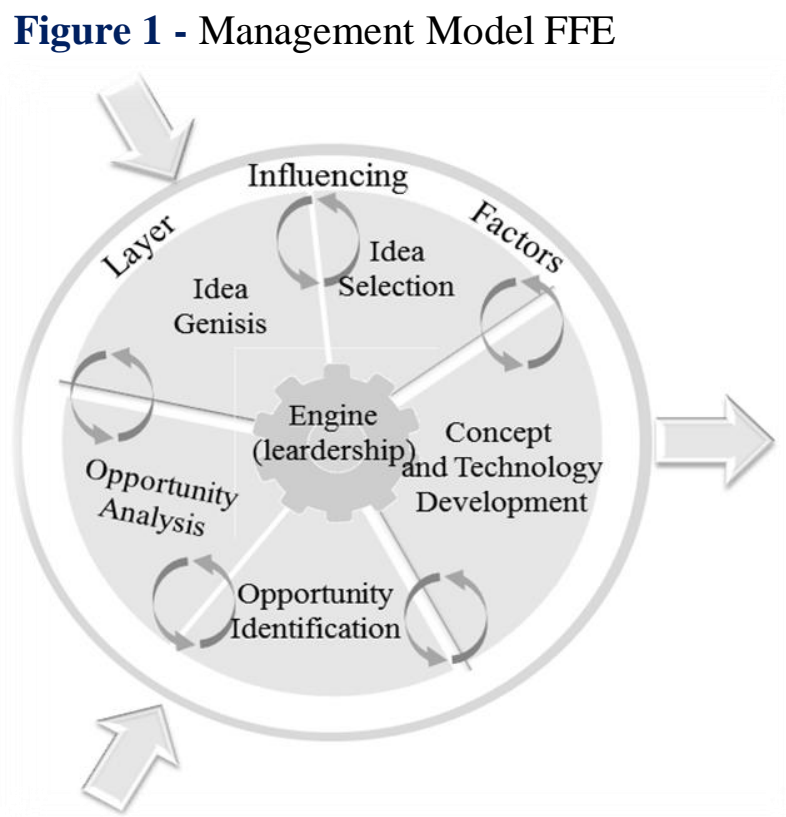

Source: Koen et al., 2001.

The Koen et al. (2001) model proposed in Figure 1 has five internal layers, an outer layer and a central engine, besides the circular arrows that represent iteration between the internal layers. This can be represented in three perspectives:

- The layer of "influencing factors" - consists in the organizational competences (extra PPD), the business strategy, the external "world" (i.e., distribution channels, customers and competitors) and the evolution of science and technology to be used;

- The inner area - the five segments of the circle - defines five stages, namely: Opportunity Identification, Opportunity Analysis, Genesis of the Idea, Idea Selection and Concept;

- The engine - maintains the cohesion and the cadence of the model and it is driven by the leadership and organization's culture.

\subsubsection{Enablers in FFE management}

Vigna and Miyake, (2006) report the capability building as a result coming from the interaction between enablers composed of organizational resources and operational techniques. When coordinated and aligned efficiently, they generate a competence in a respective functional 
area. It is expected that by using these enablers the company tends to have a more efficient management of the FFE, which results in agility, cost reduction and commercial success of the new design.

In order to obtain such enablers, the authors conducted a survey in the literature for a total of 14 references between books and academic journals focused on Administration, Production, Operations Management, Innovation and Strategic Planning. We found different elements with different designations, which were grouped in 13 elements. We divided the enablers into 4 clusters: Continuous Learning (CL), Ideation(ID), Client's Needs (CN), Project Decisions (PD). The first, (CL), provides the FFE with the necessary knowledge to generate the second one, (ID), and this, in turn, provides subsidies to reach the third one, (CN). And the last one, (PD), coordinates the others in order to seek the initiatives that are aligned to the business needs. To clarify,, Figure 2 shows a representation of this description, and Table 1 shows the results.

Figure 2 - Representation of the task of each cluster in FFE Management
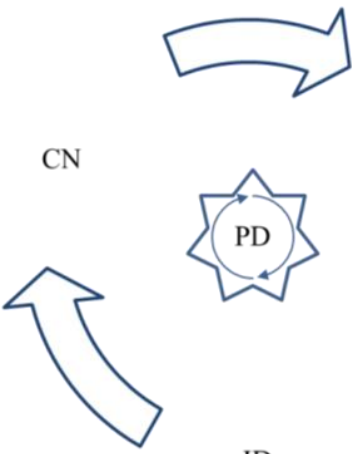

CL

ID

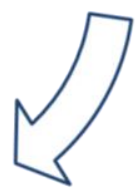

Source: Authors. 
Table 1 - Enablers of FFE

\begin{tabular}{|c|c|c|c|}
\hline Cluster & Enablers & Stages & Authors \\
\hline \multirow{4}{*}{$\begin{array}{l}\text { Continuous } \\
\text { Learning }\end{array}$} & Knowledge Management & Cross & {$[1,7,8,10,13,17,18,19,24]$} \\
\hline & Multifunctional teams & Cross & {$[7,8,10,11,14,17]$} \\
\hline & Horizontal Collaboration & Cross & {$[7,10,11,14,1 \mathrm{~g}$} \\
\hline & Employee Researcher & Cross & {$[1,11,14]$} \\
\hline \multirow{2}{*}{$\begin{array}{l}\text { Perception and } \\
\text { Suggestion }\end{array}$} & Ideas Generation & Idea & {$[4,11,23,24]$} \\
\hline & Ideas Database & Idea & {$[11,14,25]$} \\
\hline \multirow{4}{*}{ Client's Needs } & Customer Involvement & Cross & {$[7,10,11,14,17,19]$} \\
\hline & Market Analysis & Opportunity & {$[8,10,11,23]$} \\
\hline & Quality Function Deployment (QFD) & Opportunity & {$[8,14,24]$} \\
\hline & Acceleration of Information & Idea & {$[8,24]$} \\
\hline \multirow{3}{*}{ Project Decisions } & Leadership & Cross & {$[7,10,11,14,23]$} \\
\hline & Business Case & Opportunity & {$[11,14]$} \\
\hline & Project in Parallel & Idea & {$[8,10]$} \\
\hline
\end{tabular}

Source: Authors.

The literature quoted at Table 1 is as follows:[1] Alblas and Jayaram (2014), [4] Currano and Steinert (2012), [7] Hyypiä and Parjanen (2013), [8] Jetter (2003), [10] Kim and Wilemon (2002), [11] Koen et al. (2001), [13] Lynn, Morone and Paulson (1996), [14] Mendes and Toledo (2011), [17] Sandmeier et al (2004), [18] Stevens (2014), [19] Thanasopon et al. (2013), [23] Verworn (2009), [24] Verworn and Herstatt (2001). Table 2 shows the groups and contains the 13 most cited enablers out of a total of 36 . These 36 enablers are the result of a survey's compilation in a list of more than 170 citations found in 14 papers. Because of the diversity of sources, it is convenient to describe the concept of each enabler.

\subsubsection{Enablers of the first cluster - Continuous Learning:}

- Knowledge Management: it is the use of knowledge maps of employees to build mental models and team decision or groups (Jetter, 2003). Knowledge management assists in the transfer of knowledge and information in an intense way between different projects about the problems and solutions, it is an appropriate technique to solve problems in an agile way (Jetter, 2003, Verworn \& Herstatt, 2001), and in the flow of information between different areas, which is an enriching idea, besides being an 
excellent tool for making the diagnosis of perceived knowledge and, therefore, a leveling of knowledge (Jetter, 2003, Kim \& Wilemon, 2002, Stevens, 2014, Thanasopon et al., 2013, Verworn \& Herstatt, 2001). Alblas and Jayaram (2014) is more specific when they point out the need for a continue iteration for specific learning, as in design projects and prototyping. Hyypiä and Parjanen (2013) mentions that "face to face" contacts assist in the dissemination of this knowledge. Stevens (2014) explains that analysis of success and failure in past development is a way to identify the nature, contribution and efficiency of learning strategies adopted to reduce the uncertainties of the FFE. Some authors describe a specific tool as a fundamental one, the "experience database". Jetter (2003) describes it as an important feature to store the experience. In this database are stored historical data, experience and insights, and once stored and organized properly, they form an important open communication channel that enables the source of information with features that meet the demand of the FFE (Kim \& Wilemon, 2002). Lynn et al. (1996) described the importance of the cycle of probe and learn, the authors state: "These companies developed their products by probing potential markets with early versions of the products, learning from the probes, and probing once again";

- Multifunctional teams: the adoption of multi-functional teams increase integration and the speed of transferring information through different functional areas reducing the execution time of the FFE (Jetter, 2003, Kim \& Wilemon, 2002, Koen et al., 2001). Sandmeier et al. (2004) state that multi-functional teams increase assertiveness and agility in decision making in the FFE. Hyypiä and Parjanen (2013) report the importance of integration of employees from different functional areas for the enrichment of ideas and for a feasible FFE result;

- Horizontal Collaboration: this technique recommends the collaboration between companies and institutions, using third party suppliers, research centers and universities (Hyypiä \& Parjanen, 2013, Jetter, 2003, Kim \& Wilemon, 2002, Mendes \& Toledo, 2011, Thanasopon et al., 2013, Vega-Jurado, Kask \& Manjarrés-Henriquez 2017). The increased information flow accelerates the technology exchange. This integration accelerates the process of generating ideas with suppliers experience and with the addition of complementary competence (Kim \& Wilemon, 2002, Thanasopon et al., 2013). Soares, Barboza and Paula (2016) presented a framework to manage an absorptive capacity using the alliance portfolios to leverage the innovation performance; 
- Employee Researcher: it is important to have PhDs on staff scientists (Koen et al., 2001). Mendes and Toledo (2011) point to cross-functional technical need, with technical ability of research and development departments, marketing, technical support and more. Having employees with specific and necessary skills for the project is a dynamic and important task to achieve the goals outlined in the project (Alblas \& Jayaram, 2014).

\subsubsection{Enablers of second cluster - Perception and Suggestion:}

- Ideas Generation: techniques and resources for creativity are employed to generate ideas, as well as brainstorming sessions and the use of database aim at identifying key ideas (Koen et al., 2001). Verworn and Herstatt (2001) reported the implementation of TIPS (Theory of Inventive Problem Solving), with which it is possible to develop analogies with other existing solutions. The Delphi method can also be adopted for considerations and perceptions of technology trends. Currano and Steinert (2012) present a model in which the origin of the idea can be "triggered", "created in the leisure", "remembered from memory" or "created from other sources". Verworn (2009) states that the enrichment of ideas may come from a multi-disciplinary approach and socialization team with face-to-face meetings;

- Ideas Database: it is a formal activity of opportunity identification (Koen et al., 2001). Through Ideas Database different functional areas of the company participate in the generation and even the selection of ideas (Mendes \& Toledo, 2011). The database does not need to be restricted into the company and it should be extended to partners from Horizontal Collaboration (research center, suppliers, university, etc.);

\subsubsection{Enablers of third cluster - Client's Needs:}

- Customer Involvement: At the beginning of the FFE process, customer engagement is not only important, but the direct contact with the client in fact increases the process of enrichment of ideas (Kim \& Wilemon, 2002, Koen et al., 2001, Mendes \& Toledo, 2011, Sandmeier et al., 2004). In addition, (Hyypiä \& Parjanen, 2013, Thanasopon et al., 2013) reported that customer participation reduces market uncertainty;

- Market Analysis: enables the competitive intelligence and trend analysis which, in turn, enables the analysis of risk versus investment permitting the alignment between 
the needs of the market and the company's ability (Kim \& Wilemon, 2002, Koen et al., 2001). Verworn (2009) mentions that the deeper and more detailed the knowledge of the market, the lower the uncertainty in the FFE;

- Quality Function Deployment (QFD): it is the adoption of customer expectations of translation techniques in product specification (Jetter, 2003, Mendes \& Toledo, 2011, Verworn \& Herstatt, 2001). Jetter (2003) points the use of QFD as a methodology for awareness of perceived value composed of an array of the following perspectives: client request, competitive environment, target value, importance of the customer. Sandmeier et al (2004) state that this translation can be performed with the aid of the internet, where the client identifies the most desirable characteristics of the product;

- Acceleration of Information: Jetter (2003) indicates a technique to obtain a customer's reliable judgment about future products, through which the future can be simulated. Lacom, et al. (2017) report a framework where the users are leading the process of innovation. Verworn \& Herstatt (2001) complements this description as a method that puts potential customers in a virtual environment and measures the probability of buy, perceptions and preferences. The future environment is based on multimedia and often includes virtual newspaper articles, advertising or prototypes. A customer can choose the sources of information he would normally use to make a purchase decision. This specific approach overcomes the weaknesses of conventional techniques that do not allow the client to imagine a future environment and present only a small amount of information that may not be relevant for purchasing decisions. The acceleration of information is only recommended for high-risk products that require large investments;

\subsubsection{Enablers of fourth cluster - Project Decisions:}

- Leadership: it highlights that the role of leadership is to ensure the commitment and executive support for the success of the FFE initiatives by accelerating the generation of ideas (Hyypiä \& Parjanen, 2013, Kim \& Wilemon, 2002, Koen et al., 2001, Mendes and Toledo, 2011). Verworn (2009) informs that leadership is crucial to the motivational factor of the employees. Mendes and Toledo (2011), in turn, argue that the critical factors that the leader must have to manage an initiative in the FFE are: having technical knowledge, good interpersonal skills, ability to motivate staff, authority to make decisions, ability to manage conflict and communicate clearly, bargaining power with 
executives (to get more technical and financial resources if necessary). We emphasize the importance of leadership in providing free time for developers to work on their own initiatives when it comes to the FFE;

- Business Case: Koen et al. (2001) - it is based on models that assist in market risk and investment in technology based on information as a competitive, organizational capacity, unique competitive advantages and financial returns. Mendes and Toledo (2011) report the importance of checking the quality of analysis versus financial return during the FFE;

- Project in Parallel: Jetter (2003) indicates this technique as a possibility to enrich ideas, whereas Kim and Wilemon (2002) show it as a technique that considers the greatest number of ideas as possible leading in parallel pre-prototype of different initiatives.

Other important and relevant enablers were cited by several authors, such as having efficacy in project management, or using the "leader user" technique. However, even though these are relevant, we did not consider them in this paper either because it contains few citations, or because it already has been, in a sense, represented by the elements cited above. As a result, it is expected that, once the FFE enablers have been applied, the company achieves a status quo of innovation culture. Koen et al. (2001) claim that, in general terms, the company must have a culture of innovation, as an environment conducive to the culture of innovation as: challenges set by allowing the emotional involvement with the project, that considering the incentivation of an enabling environment to take risks, liberty to express opinions, with sufficient time to generate ideas and resources to design new ideas. Many ideas come from the "shop floor", employees and middle management, as well as the environment with a supportive and reliable atmosphere and a culture of innovation generates intrinsic motivation for promoting innovation (Hyypiä \& Parjanen, 2013).

\section{Methodology}

To investigate how a company should manage its resources and processes to efficiently manage the FFE phase of the PPD, this work included conducting field research based on the case study method. The adoption of this method implies empirically the investigation of a contemporary phenomenon within its real context in which the contextual conditions are highly relevant to the phenomenon focused as a case (Yin, 2001). Eisenhardt (1989) says that 
qualitative research has limitations, such as: greater difficulty in determining the validity and reliability of the results considered subjective, and difficulty to replicate, concerning qualitative complex projects that complicate the construction of theory, and design not always widespread when it comes to conclusions.

The development of this paper was divided into two stages. Initially, the research concerning question Q1 - "What are the organizational resources and operational techniques that enable the company to efficiently manage the FFE?" - it relied in conducting a literature review to identify organizational resources and operational techniques in the context of FFE Management considered in the literature. The results of this literature review were organized in sections 2.2.1 and 2.2.2. The literature review is used to know the state of the art in the subject of interest, and the case study is used for the exploration of empirical phenomena (Eisenhardt, 1989). To investigate question Q2 - "Are organizational resources and operational techniques found in literature review applied to the company's case?" A preliminary study was conducted in order to explore, in the context of international industry sectors, which businesses are characterized by being innovative, as shown in Table 2 .

Table 2 - Innovative Companies

\begin{tabular}{|c|c|c|c|}
\hline Rank & $\begin{array}{c}\text { Number of } \\
\text { Patentes (2013) }\end{array}$ & Company & Sector \\
\hline 1 & 6809 & International Business Machines (IBM) & High Technological \\
\hline 2 & 4676 & Samsung Electronics Co Ltd KR & High Technological \\
\hline 3 & 3825 & Canon K K JP & High Technological \\
\hline 4 & 3098 & Sony Corp JP & High Technological \\
\hline 5 & 2660 & Microsoft Corp & High Technological \\
\hline 6 & 2601 & Panasonic Corp JP & High Technological \\
\hline 7 & 2416 & Toshiba Corp JP & High Technological \\
\hline 8 & 2279 & Hon Hai Precision Industry Co Ltd TW & High Technological \\
\hline 9 & 2103 & QUALCOMM Inc & High Technological \\
\hline 10 & 1947 & LG Electronics Inc KR & High Technological \\
\hline
\end{tabular}

It is evident from Table 2 that the High-Tech companies bring the feature of being innovative and a large number of patents, probably due to the high competitiveness of the sector. The case of this paper is done with a company in the high-tech sector that operates in the Brazilian market. Therefore, this case in high-tech sector was selected to investigate Q2. This choice was also motivated by the fact that they are industries that often stand ahead in terms of adoption of more modern practices and technologies.

Building theory from case studies is a research strategy that involves using one or more cases to create theoretical constructs, propositions and/or theory from case-based, empirical 
evidence. The constructs and variables are defined in order to assist in the coordination of events, in the construction of data collection instruments, data analysis and conclusions (Eisenhardt, 1989). In order to exemplify that in a unit, we have selected the case of a multinational supplier of high-tech service. Its main office is installed in São Paulo State, Brazil. Data collection relied on direct observation method without intervention actions. This research was done in just one case due to the fact that the company is leader in the generation of patents, applies the best practices, has offices in several countries and capital opened in stock exchange values, which explains why it is considered a company with mature governance and management processes. For this reason, we approached this only company, as we believe it would be a benchmark in the FFE. Naturally, that may be a limitation for this research, so we suggest a future study in order to explore the same method in other companies.

At least two managers were interviewed - a high and a middle management - following a semi-structured interview (4 hours each) and later follow-up with them for validation of data collected and elucidation of specific issues identified during the visit. Sometimes meetings were scheduled, respecting the inductive method proposed by (Eisenhardt, 1989) in 4 more hours each. In conducting the field work, observations and data surveys were directed in order to be able to understand how the application enablers contribute to the reduction of FFE uncertainties as illustrated in Figure 3.

In the field work the main practices were noted, where we were invited to participate as listeners to accomplish our research. In this dynamic, it was possible to verify, through a previous checklist as well as the interviews and literature review, the application of some tools proving their effective use. The objective of this system was to triangulate, among the tools found in the literature review, interviews with managers and on-the-spot verification.

Figure 3 - Uncertainties of the FFE and its relationship with enablers

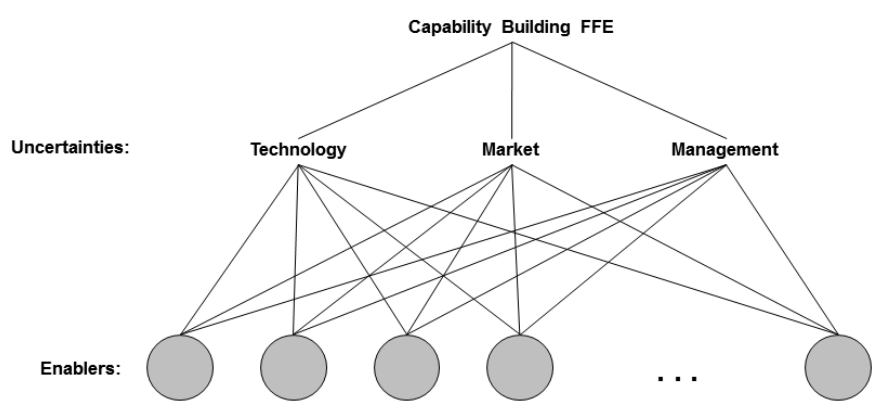

Source: Created by author based in Vigna and Miyake (2006). 


\section{Case}

The purpose of the case was to search for data to better understand if "organizational resources and operational techniques found in literature review are applied to the company's case" (Q2). For this, in the research performed with the high-technology company, we examined how the elements shown in Table 1 are applied in their innovation projects. The case is a multinational company providing high technology services, working with solutions to support back office and front office, social media, cloud computing, among others. This company was selected for the case because it features a great focus on innovation and patents production.

\subsection{Company features}

The company has several research laboratories and development of new technologies, with the function of producing science for marketing purposes, differently from the non-profit research centers, such as universities and foundations. These laboratories operate two modi operandi in innovation: MP, driven by the customer, and the TP innovation, designed by using new technology patented by the company as shown in Figure 4, which provides an overview of the stages in the innovation area to operate MP or TP. In the modus operandi MP, the process starts with the customer's need, where the opportunity comes. First, the employee will check the company's database to see if there is already a solution to this need in another innovation center of the company. When that cannot be not found, the employee dives into the universe of journals and academic research to check if there is a solution to this customer need. When not found in the academic source, the employee initiates the stage of ideas and, subsequently, concept, where you create a blueprint for the functional requirements of the product to be created. This blueprint is directed to the laboratory that will be responsible for the PPD process, and, after it is ready, the product is patented by the company and implemented on the client. 
Figure 4 - Modus Operandi innovation area of company's case

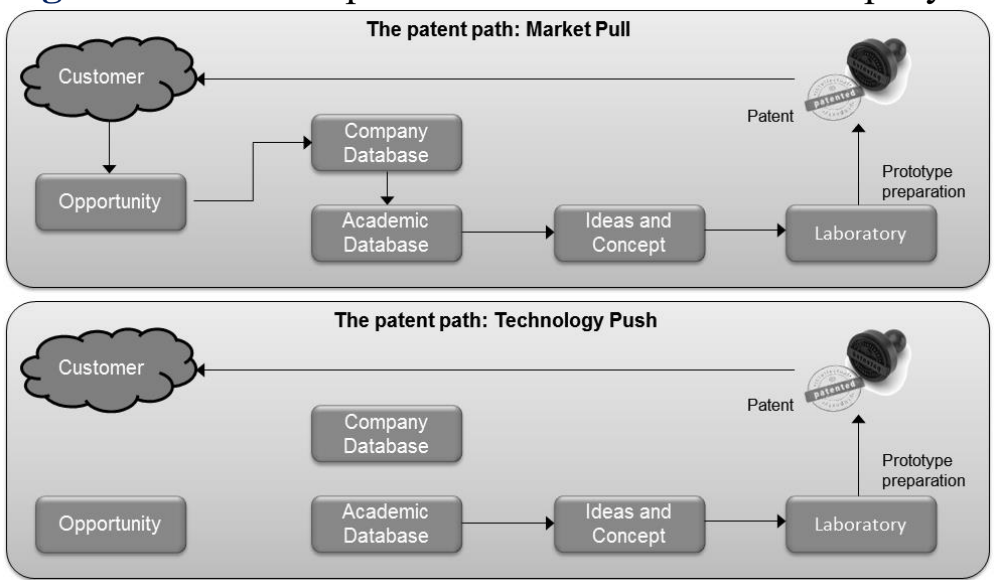

Source: Authors.

When the modus operandi is TP, the steps change, because there is no opportunity coming from the client, and so, the product to be created will be pushed to the client. They do a scan at the academy database to verify which gaps and issues have not been addressed yet. The remaining processes are similar to that of MP: the idea, the concept, the laboratory with the PPD, the patent. Although, in the end, it is necessary to search for a client to be a sponsor of this product. But, even in TP, the client is always involved, because the project needs a sponsor and a potential portfolio of clients (more than one). The drivers of the labor are: a) production of articles in academic periodicals, b) produced patents, c) innovations that have generated impact on the customer and revenue for the company. The type of innovation, MP or TP, influences the drivers, as illustrated in Figure 5.

Figure 5 - Modus operandi and impact on key points

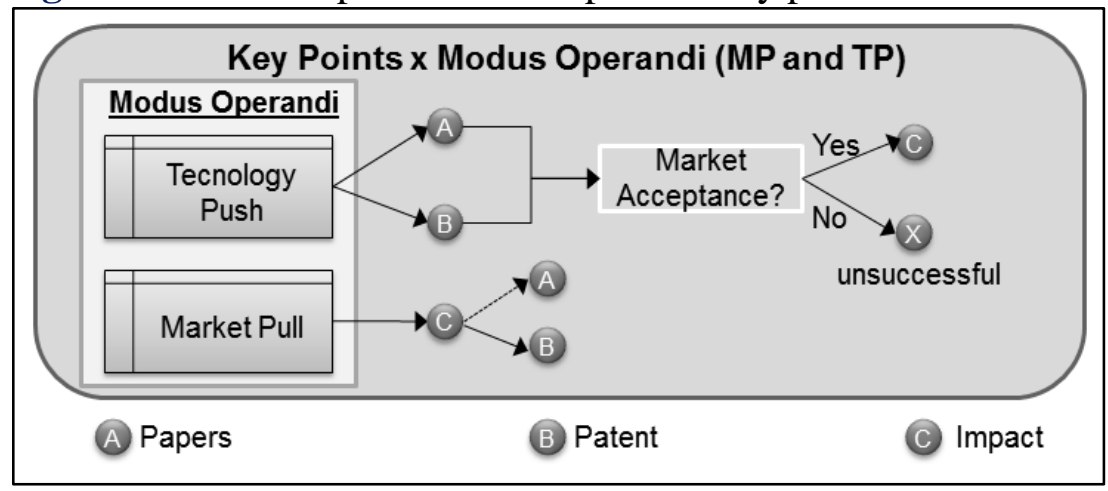

Source: Authors.

The figure shows that the modus operandi TP generates patents and papers, but sometimes it is notsuccessful. However, the modus operandi MP breeds success, generating papers and patents. Historically, the company is known for being at the vanguard of the world 
science, and its employees are granted several awards, such as the Nobel Prize. For this reason, the company has always worked in the modus operandi TP. However, due to a great number of changes in the competitive environment, the company is changing its cultural features for MP.

\subsection{FFE in the company}

The interviews and visits showed that the company has a mature management structure of innovation (both in the FFE and the PPD). The specific analysis performed on the FFE showed that large portions of the company adopt enablers shown in Table 2. The result of this analysis follows by clusters:

\subsubsection{Cluster of Continuous Learning}

- Knowledge Management: the company uses this technique to its fullest, using a map of employee knowledge and collaboration network for global enrichment of ideas. As for the "experience database" tool, despite having portals where employees can maintain network, maintain documentation and exchange experiences, it is not used with adherence;

- Multifunctional Teams: Having always been an employed technique, all innovative project is under the responsibility of a multidisciplinary team, for example: engineers, designers, anthropologists, IT professionals, psychologists, etc. The team is built on demand, and the leader decides which specific skill will be useful. You can recruit professionals from other development areas as well. What's more, the changing area is motivated to seek development skills and the holistic view of the employee;

- Horizontal Collaboration: engagement with the client previously mentioned, in the TP innovation, can be understood as part of the Horizontal Collaboration. The company creates links with universities to research, but the limit for this type of partnership lies in the problems generated in relation to intellectual property innovation. Therefore, generally, these partnerships are obtained with the objective of complementary competence;

- Employee Researcher: employees involved with the phase of the FFE are usually scientists or $\mathrm{PhD}$. There are also employees from support area, such as finance, who do not havethis academic background. 


\subsubsection{Cluster of Perception and Suggestion}

- Ideas Generation: activities like brainstorming, application of the Delphi method, or the TIPS logic were cited as techniques for generating ideas. Some ideas come from other preexisting solutions - TIPS logic, but this technique is limited due to difficulties in terms of the generation of innovation patent. The biggest obstacle is not the generation of ideas, but the decision-making of which idea will turn into a prototype and later a concept. For this reason, the ideas must always be refined in terms of time, cost and demand to assist in this decision-making process, as a kind of a stage gate of ideas;

- Idea Database: There is no formal channel to report ideas, only informal channels, such as emails or web portal with specific forums. Still, the company has a global network with a channel through which it is possible to exchange ideas or improve them.

\subsubsection{Cluster of Client's Needs}

- Customer Involvement: as it might be expected, in the MP innovation, the customer engagement is full, because it is the innovation triggering agent. It is interesting to note that even in the TP innovation the customer may also be involved, although not as the innovation generator. When a TP innovation is already with an idea pilot ready, the company seeks potential customers for this potential product, and offers a joint development partnership, and, in return, they have the opportunity to be the first customer to have the product;

- Market Analysis: a technique that isperformed periodically seeking greater visibility for the generation and selection of ideas;

- Quality Function Deployment: the company adopts a model that is similar to QFD, and so the company can obtain a relationship matrix, however, changing the elements to be crossed and the weight of the features;

- Acceleration information: the company adopts a mechanism that is similar to this technique that involves the client to test ideas that already have a developed pilot (idea pilot). For example, you can put together a presentation to test the idea on the client, seeking suggestions for improvements; 


\subsubsection{Cluster of Project Decisions}

- Leadership: it has a key role in the process as a whole, from team building, negotiation for resource request with company executives, to timely negotiation with the customer to obtain a more favorable environment for reviewers. For example, during the development of the project, agree with the client that the project may be published as a case in an academic journal. This is a motivating factor for the employee when they have a $\mathrm{PhD}$ degree. $\mathrm{Wu}$ and Cormican (2006) explore the importance of a high-quality leadership to increase the effectiveness of an innovation process, specially the creativity;

- Business Plan: they elaborate a business plan answering basic questions throughout every project, such as: Who is the client? How much is the demand? What is the cost? Is there a potential investor? The proposal can be very interesting and generate a good impact, but if it is designed only for a specific client, there isn't gain of scale,

- Project in Parallel: this technique is not widely used because resources are limited, which makes it economically unfeasible to adopt. It is possible to have teams developing similar ideas but for different products, such as developing algorithms for analyzing unstructured data.

From the selected enablers analyzed, it is understood that the company adopts $8(62 \%)$, 4 partially (31\%) and only 1 element is not adopted (7\%). Table 3 presents a summary of the adoption of resources and the FFE management techniques.

Table 3 - Enablers adopted by the company

\begin{tabular}{|c|c|c|c|c|}
\hline Cluster & Enablers in FFE & $\begin{array}{l}\text { Adopts in } \\
\text { the fullness }\end{array}$ & $\begin{array}{l}\text { Partially } \\
\text { adopts }\end{array}$ & $\begin{array}{c}\text { Does not } \\
\text { adopt }\end{array}$ \\
\hline $\mathrm{CL}$ & Knowledge Management & $\sqrt{ }$ & & \\
\hline$C L$ & Multifunctional Teams & $\sqrt{ }$ & & \\
\hline$C L$ & Horizontal Collaboration & & $\sqrt{ }$ & \\
\hline$C L$ & Employee Researcher & $\sqrt{ }$ & & \\
\hline PS & Ideas Generation & $\sqrt{ }$ & & \\
\hline PS & Ideas Database & & $\sqrt{ }$ & \\
\hline $\mathrm{CN}$ & Market Analysis & $\sqrt{ }$ & & \\
\hline $\mathrm{CN}$ & Customer Involvement & $\sqrt{ }$ & & \\
\hline $\mathrm{CN}$ & Quality Function Deployment & & $\sqrt{ }$ & \\
\hline $\mathrm{CN}$ & Acceleration of Information & & $\sqrt{ }$ & \\
\hline PD & Leadership & $\sqrt{ }$ & & \\
\hline PD & Business Case & $\sqrt{ }$ & & \\
\hline PD & Project in Parallel & & & $\sqrt{ }$ \\
\hline & 13 & 8 & 4 & 1 \\
\hline & $100 \%$ & $62 \%$ & $31 \%$ & $7 \%$ \\
\hline
\end{tabular}

Source: Authors. 
In addition to the verification of the implementation of enablers in FFE management, it was established through interviews that these elements contribute to the reduction of uncertainties from the FFE. To prepare Table 4, interviews asking about how the enablers help to reduce the FFE uncertainties were conducted.

Table 4 - Contribution of the implementation of enablers to reduce FFE uncertainties

\begin{tabular}{|c|c|c|c|c|}
\hline Cluster & Enablers in FFE & $\begin{array}{l}\text { Technology } \\
\text { Uncertainty }\end{array}$ & $\begin{array}{c}\text { Market } \\
\text { Uncertainty }\end{array}$ & $\begin{array}{c}\text { Management } \\
\text { Uncertainty }\end{array}$ \\
\hline $\mathrm{CL}$ & Knowledge Management & $\sqrt{ }$ & & $\sqrt{ }$ \\
\hline $\mathrm{CL}$ & Multifunctional Teams & & & $\sqrt{ }$ \\
\hline$C L$ & Horizontal Collaboration & $\sqrt{ }$ & $\sqrt{ }$ & \\
\hline$C L$ & Employee Researcher & $\sqrt{ }$ & $\sqrt{ }$ & $\sqrt{ }$ \\
\hline PS & Ideas Generation & & $\sqrt{ }$ & \\
\hline PS & Ideas Database & & & $\sqrt{ }$ \\
\hline $\mathrm{CN}$ & Market Analysis & & $\sqrt{ }$ & \\
\hline $\mathrm{CN}$ & Customer Involvement & $\sqrt{ }$ & $\sqrt{ }$ & \\
\hline $\mathrm{CN}$ & Quality Function Deployment & & $\sqrt{ }$ & $\sqrt{ }$ \\
\hline $\mathrm{CN}$ & Acceleration of Information & & $\sqrt{ }$ & $\sqrt{ }$ \\
\hline PD & Leadership & $\sqrt{ }$ & $\sqrt{ }$ & $\sqrt{ }$ \\
\hline PD & Business Case & & $\sqrt{ }$ & $\sqrt{ }$ \\
\hline \multirow[t]{3}{*}{ PD } & Project in Parallel & & $\sqrt{ }$ & $\sqrt{ }$ \\
\hline & & 5 & 10 & 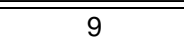 \\
\hline & & $38 \%$ & $77 \%$ & $69 \%$ \\
\hline
\end{tabular}

Source: Authors.

Table 4 shows that many elements contribute in reducing technical uncertainties of the company, and to a smaller extent for the management of uncertainty, but in general it is possible to verify that the three uncertainties listed suffer reduction with the application of these elements.

\subsection{Success of developed projects}

The company develops several innovative projects in the area of high-tech services, such as the development of intelligent algorithms. The company splits innovative projects into two categories, the radical innovation projects and incremental innovation projects. Radical projects can be understood, by the classification of Clark and Wheelwright (1993), as a project of radical innovations. The projects featured in this company as incremental innovation can be characterized as project derivatives and, sometimes, when applicable, platform projects (when innovation allows coupling of another product to create a third one).

In the environment of a company, radical innovation projects are projects featuring "technology triggers" because they have little visibility by the customer, being pioneers in a certain technology, which, generally, was previously nonexistent. This usually arises when the 
company develops, or is entitled to to, a technology and through it intends to prospect products for the market. In this situation, the company activates its team of collaborators to dive into the FFE phase and create successful products. Before convincing the potential usefulness of this customer, the FFE of the employees team must first convince the leader employees of the company. They are responsible for the "go / no go" decision-making that interfaces with the phase of the FFE and the PPD. This is the first major obstacle because the radical innovation is difficult to be presented as successful products to decision makers, since there is no market developed yet. With regards to the FFE phase, the great difficulty is to reduce market and management uncertainties in order to achieve the approval and elaborate the product concepts created in the FFE. In this type of project, the market uncertainties are usually as follows: existing customers to this product, if these customers are willing to pay for the product, if these products can cannibalize other products of the company's portfolio andwhen the client will be able to use this product.

The managerial uncertainties: if we have technical staff to do this, if we have resources, financial budget, if this product is aligned with the company's product strategy and if this project provides return on investment to be made. When it comes to incremental innovation projects, such as the analysis of social media, market uncertainty and managerial uncertainty are no obstacles, since it is known who the potential customers are, and how much they are able to pay, which resources are required for the project and what the return to be obtained with this product is. This justifies that this kind of incremental innovation project meets the "peak of expectation" of the curve in Figure 8, as the market is already "starving" for this product. For example, many customers monitor social media and websites looking for insights to improve their product, but it is all done manually. An automated solution would reduce the cost, time and increase detection efficiency. However, at the same time, there are many competitors with similar products, so, for the product to be truly innovative, the company must innovate in technology differentiation. In this way, this feature will give to the product a status of "peak of expectation" in the curve. This innovation leads to the emergence of technological uncertainty, and, therefore, the need to reduce this uncertainty. Examples of technological uncertainty: if this middleware actually runs on different operating systems, the transaction processing speed limit of our new database, etc.

As for the other phases of Figure 8, it should be stated that innovative projects are not characterized in these phases. This phase is related to the diffusion of innovation, i.e., the products in these phases have been innovative in the past and passed through the first two phases 
of the curve, and now they are best known in the market. For the case, this phase is not applicable because there is no innovation, however, these products are always in the company's radar since they serve as a base or platform for the development of new incremental innovation projects. Table 5 summarizes the main differences between the uncertainties, radical innovation project and incremental innovation project.

Table 5 - Innovation Project: radical x incremental

\begin{tabular}{llcc}
\hline \multicolumn{1}{c}{ Uncertainty } & \multicolumn{1}{c}{ Example of Issues } & $\begin{array}{c}\text { Radical } \\
\text { Innovation } \\
\text { Project }\end{array}$ & $\begin{array}{c}\text { Incremental } \\
\text { Innovation } \\
\text { Project }\end{array}$ \\
\hline Technology & $\begin{array}{l}\text { The company has the necessary technology to } \\
\text { achieve the success of this innovation? }\end{array}$ & Yes & Not \\
Market & $\begin{array}{l}\text { Is there a market for this product currently or in } \\
\text { the short time (1 year)? }\end{array}$ & Not & Yes \\
Management & $\begin{array}{l}\text { Does the return on investment estimates were } \\
\text { performed on reliable? }\end{array}$ & Not & Yes \\
\hline
\end{tabular}

Source: Authors.

From this table it is possible to abstract that the radical innovation projects present the main obstacle to reducing marketing and management uncertainties, whereas incremental innovation projects have as their main obstacle the reduction of the technological uncertainty. With this information, we can infer which enablers are critical success factors for radical and incremental innovation projects. Crossing Table 5 and Table 4 provides the information as for which uncertainty element helps in reduction, producing, in turn, Table 6, which shows the critical success factors of each category of innovation project.

$\underline{\text { Table } 6}$ - Critical Success Factor by category of innovation project

\begin{tabular}{clcc}
\hline Cluster & \multicolumn{1}{c}{ Enablers in FFE } & $\begin{array}{c}\text { Radical } \\
\text { Innovation } \\
\text { Project }\end{array}$ & $\begin{array}{c}\text { Incremental } \\
\text { Innovation } \\
\text { Project }\end{array}$ \\
\hline $\mathrm{CL}$ & Knowledge Management & $\sqrt{ }$ & $\sqrt{ }$ \\
$\mathrm{CL}$ & Multifunctional Teams & $\sqrt{ }$ & $\sqrt{ }$ \\
$\mathrm{CL}$ & Horizontal Collaboration & $\sqrt{ }$ & $\sqrt{ }$ \\
$\mathrm{CL}$ & Employee Researcher & $\sqrt{ }$ & \\
$\mathrm{PS}$ & Ideas Generation & $\sqrt{ }$ & \\
$\mathrm{PS}$ & Ideas Database & $\sqrt{ }$ & $\sqrt{ }$ \\
$\mathrm{CN}$ & Market Analysis & $\sqrt{ }$ & \\
$\mathrm{CN}$ & Customer Involvement & $\sqrt{ }$ & \\
$\mathrm{CN}$ & Quality Function Deployment & $\sqrt{ }$ & \\
$\mathrm{CN}$ & Acceleration of Information & $\sqrt{ }$ & \\
PD & Leadership & $\sqrt{ }$ & \\
PD & Business Case & $\sqrt{ }$ & \\
PD & Project in Parallel & 13 & $38 \%$ \\
& & $100 \%$ &
\end{tabular}

Source: Authors. 
This result is aligned with Clark and Wheelwright (1993) mentioning that incremental innovation projects require fewer resources than the radical innovation. It should report that if an element is not a critical success factor, it does not mean that it is not necessary, as is the case, for example, of the use of multifunctional teams for incremental innovation projects. This inclusion is necessary, but does not help to reduce technological uncertainty, which is the major obstacle of this type of project, and, therefore, for this type of project it is not a critical success factor. All elements are critical success factors for radical innovation projects, but only 5 items (38\%) can be considered critical success factors for incremental innovation projects. In case of incremental innovation project, this does not mean that the other enablers are not important.

\section{Conclusion}

This article aimed at answering the two research questions: Q1) What are the organizational resources and operational techniques that enable the company to efficiently manage the FFE? Based on a literature review focused on enablers in the FFE, a number of enablers were collected, and out of these, 14 were selected elements most often cited by the authors as enablers. We divided these enablers in 4 interdependent clusters, to obtain a holistic approach of the enablers, as shown in Table 2. Such enablers consist of organizational resources and operational techniques that, once synchronized, can enable the company in a given functional competence. That, in this case, relates to the company's innovation process and specifically the FFE phase. Capacity building in the FFE is obtained when the enablers provide subsidies to operate efficiently in the five phases of the model (Koen et al., 2001), reducing the 3 main uncertainties typical of the FFE phase: Technological uncertainty, market uncertainty and managerial uncertainty.

Q2) Are organizational resources and operational techniques found in literature review applied to the company's case? The case is a multinational company providing high technology services, focused on innovation and renowned for being one of the most innovative companies in the world, which generates the greatest number of patents. We interviewed two middle level managers in order to understand what the dynamics of innovation in the company are and the elements mapped in the literature that are applied in the company. The company categorizes two types of innovation projects, radical innovation and incremental innovation. In this way, it was found that $99 \%$ of the mapped enablers are applied in the company, in whole or in part. It was mapped, according to the view of respondents, which elements are responsible for the reduction of which uncertainties. They also found what kind of uncertainty most affects the 
different categories of the projects, so that it was possible to find what type of element is a critical success factor for radical projects and incremental projects.

An important point found in the case study was the difficulty that the decision makers have to determine a "go / no go" decision in radical innovation. This happen because of the difficulty in reducing marketing and management uncertainties. It was estimated that such a decision is tacit, and, therefore, depends more on the experience and the intuition of the decision makers. A very important contribution is the framework elaborated to assess the process's maturity of the FFE Management in the case. Through a series of interviews it was possible to see if the enablers were applicable in the FFE Management, and how these enablers could influence to reduce the main uncertainties in technology, market and management. As a future research, the present authors suggest to apply the same study in other enterprises to see if this is a common practice, and, in addition, we also suggest to explore SME (Small and Medium Enterprises) to better understand the gap between the FFE practices in different companies sizes.

\section{Reference}

Alblas, A., \& Jayaram, J. (2014) Design resilience in the fuzzy front end (FFE) context: an empirical examination. International Journal of Production Research, December.

Berghaus, S., \& Back, A. (2017) Disentangling the Fuzzy Front End of Digital Transformation: Activities and Approaches. ICIS 2017 Proceedings. Thirty Eighth International Conference on Information Systems, South Korea.

Chamakiotisa, P., Boukisa, A., Pantelib, N., \& Papadopoulosc, T. (2020) The role of temporal coordination for the fuzzy front-end of innovation in virtual teams. International Journal of Information Management 50 182-190.

Clark, K. B., \& Wheelwright, S.C. (1993) Managing new product and process development. New York: The Free Press.

Currano R. M., \& Steinert M. (2012) A Framework for Reflective Practice in Innovative Design. International Journal of Engineering Education Vol. 28, No. 2, pp. 270-274 Eisenhardt, K. M. (1989) Building theories from case study research. Academy of Management Review, 14: 532-550.

Hyypiä, M, \& Parjanen, S. (2013) Boosting Creativity with Transformational Leadership. Interdisciplinary Journal of Information, Knowledge, and Management Volume 8.

IFI CLAIMS ${ }^{\circledR} 2013$ Top 50 US Patent Assignees available in: https://www.ificlaims.com/rankings-misc-top-50-2013.htm. 
Jetter, A. J. (2003) Educating the guess: strategies, concepts and tools for the fuzzy front end of product development. In: Portland International Conference on Management of Engineering and Technology (PICMET). Anais p. 261-273. Portland/USA: IEEE.

Khuran, A., \& Rosenthal, S. R. (1997) Integrating the fuzzy front end of new product development. Sloan Management Review, v. 38, n. 2, p. 103-120.

Kim, J., \& Wilemon, D. (2002) Focusing the fuzzy front-end in new product development. R\&D Management, v. 32, n. 4, p. 269279.

Koen, P., Ajamian, G, Burkart, R, Clamen, A., Davidson, J., D’Amore, R., Elkins, C., Herald, K., Incorvia, M., Johnson, A., Karol, R., Seibert, R., Slavejkov, A., \& Wagner, K. (2001) Providing clarity and a common language to the "fuzzy front end." Research Technology Management, v. 44, n. 2, p. 46-55

Krishnan, V., \& Ulrich, K. T. (2001) Product development decisions: a review of the literature. Management Science. v. 47, n. 1, p. 1-21, Jan.

Lacom, P., Bazzaro, F., \& Sagot, J. C. (2017) Proposal of a Modelling of the Innovation Process in an International Manufacturing Company. J. Technol. Manag. Innov. Volume 12 , Issue 2.

Lynn, G. S., Morone, J. G., \& Paulson, A. S. (1996) Marketing and discontinuous innovation: The probe and learn process. California Management Review, Spring, 38, 3.

Mendes, G. H. S., \& Toledo, J. C. (2011) The Fuzzy Front End of New Product Development for Brazilian Technology-Based Companies in the Medical Device Industry: a Causal Model. Brazilian Journal of Operations \& Production Management. Volume 8, Number 1, pp. 83-102.

OECD. (2005) Oslo Manual: guidelines for collecting and interpreting innovation data. 3rd ed.

Reinertsen, D., \& Smith, P. (1991) The strategist's role in shortening product development. The Journal of Business Strategy, n 12, p.18-23.

Rodrigues, T., \& Braghini Junior, A., Sola, A. V. H. (2017) Structuring front-end innovation activities throughout strategic product planning. Production, 27.

Sandmeier, P., Jamali, N., Kobe, C. Enkel, E, Gassmann, O., \& Meier, M. (2004) Towards a Structured and Integrative Front-End of Product Innovation. R\&D Management Conference. Anais: Lisbon.

Stevens, E. (2014) Fuzzy front-end learning strategies: Exploration of a high-tech company. Technovation 34, 431-440.

Thanasopon, B, Papadopoulos, T, \& Vidgen, R. (2013) "Opening Up The Fuzzy Front-End Of Service Process Innovation: Searching Capability, Co-Development Capacity, And IT Competence". ECIS 2013 Research in Progress. Paper 22. 
Tidd, J., Bessant, J., \& Pavitt, K. (2005) Managing Innovation: Integrating Technological, Market and Organizational Change. 3rd ed. Chichesterm, UK: Wiley.

Trott, P. (2005) Innovation Management and New Product Development. 3rs ed. Upper Saddle River, NJ: Financial Times Prentice Hall.

Ulrich, K., \& Eppinger, S. (1995) Product Design and Development. p.384. New York: McGraw-Hill.

Vega-Jurado, J., Kask, S., \& Manjarrés-Henriquez, L. (2017) University industry links and product innovation: cooperate or contract? J. Technol. Manag. Innov. Volume 12, Issue 3.

Verworn, B. (2009) A structural equation model of the impact of the "fuzzy front end" on the success of new product development. Research Policy, 38, 1571-1581.

Verworn, B., \& Herstatt, C. (2001) The "Fuzzy Front End" of Innovation. Technical University Hamburg-Harburg. Hamburg: TUHH.

Vigna, C. M., \& Miyake, D. I. (2006) A conceptual framework for mass customization systems from the capability building viewpoint. In: International Conference on Production Research, Curitiba (PR) - Brazil. III ICPR - Americas`Region.

Wu, Q., \& Cormican, K. (2016) Shared Leadership and Team Creativity: A Social Network Analysis in Engineering Design Teams. J. Technol. Manag. Innov. Volume 11, Issue 2.

Yin, R. (2001) Estudo de caso: Planejamento e Métodos. 2ª ed. Porto Alegre: Bookman. 